\title{
POLRI DALAM PUSARAN PENILAIAN PUBLIK
}

\author{
Muradi \\ e-mail:muradiclark@gmail.com
}

\begin{abstract}
ABSTRAK
Setelah Polisi lepas dari militer, banyak masalah yang menghambat responsivitas polisi didalam mewujudkan polisi yang profesional dan demokratis, yang datangnya tidak hanya dari luar, namun juga dari persiapan di dalam. Terdapat dugaan yang muncul bahwa reformasi di internal polisi akan dinilai sukses ketika tuntutan memisahkan diri dari militer terealisasi. Namun, tantangan sebenarnya yang dihadapi kepolisian di era transisi demokrasi justru lebih kompleks. Artikel ini menjelaskan apa saja masalah yang dihadapi kepolisian di era transisi demokrasi dan bagaimana konteksnya di Indonesia. Artikel ini juga memberikan pendapat dari masyarakat bagaimana mengelola integrasi dari kepolisian nasional sebagai sebuah institusi agar mendapatkan respon positif dari masyarakat, dan secara individu, para anggota polisi dapat secara aktif ikutserta dan bertanggung-jawab dalam mengelola pendapat yang baik dari masyarakat.
\end{abstract}

Kata kunci: Polri, Hubungan Masyarakat, Transisi Demokrasi, Pemisahan, Sistem Pengadilan dan Kejahatan.

\begin{abstract}
After the Police separated from the Military, many problems that hinder the police response in realizing democratic police professionals, coming not only from the external but also internal readiness. There is a presumption arises that the internal police reform which is considered successful when the demands for separation from the Armed Forces realized. Yet the real challenge facing the police after separation is much more complex. This paper explained how the problems of policing era of democratic transition and how the Indonesian context. This paper also offers good opinion from the public of how integrative management of the National Police as an institution in order to get a positive response from the public, while personally, members of the police can be actively involved and responsible for managing the good opinion of the police from public.
\end{abstract}

Keywords: Polri, Public Relations, Democratic Transition, Separation, Criminal Justice System. 


\section{Pendahuluan}

Setelah lebih dari 15 tahun berpisah dari militer, Polri dihadapkan pada problem klasik yang dialami oleh hampir organisasi kepolisian di negara yang tengah menjalani proses demokratisasi. Polri bukan satusatunya institusi kepolisian yang mengalami kesulitan dalam mengartikulasikan dan mengelola antara keberhasilan dan kinerja baik Polri dengan opini publik yang terus menerus mencitrakan Polri tidak baik. Bahkan di negara yang telah memiliki tradisi demokrasi yang mapan sekalipun, kepolisiannya dihadapkan pada belum efektifnya pengelolaan kerja baik kepolisiannya dengan cibiran publik atas prilaku anggota polisi yang dianggap masih belum selaras dengan keinginan publik. ${ }^{28}$

Banyak permasalahan yang menghambat respon Polri dalam mewujudkan kepolisian demokratik yang profesional berasal bukan hanya dari eksternal semata, tetapi juga kesiapan internal dalam menyongsong dan menyikapi pemisahan Polri dari militer. Ada timbul anggapan di internal bahwa Reformasi Polri dianggap sukses manakala tuntutan untuk berpisah dari ABRI terealisasi.
Padahal sesungguhnya tantangan yang dihadapi Polri paska pemisahan jauh lebih kompleks dan cenderung menjebak apabila tidak disikapi dan direspon dengan baik.

Situasi tersebut makin rumit manakala sebagai institusi, Polri membutuhkan 'corong' yang efektif bagi sosialisasi kerja baik Polri dan penjelasan berimbang berkaitan dengan keterlibatan institusi maupun personal anggota Polri yang memiliki derajat sensitivitas tinggi. Dibutuhkan tidak hanya pimpinan atau personal yang cakap semata, tetapi juga integratif institusional yang berirama sama dalam memosisikan Polri sebagai institusi Keamanan dalam Negeri (Kamdagri) yang mampu menjawab harapan dan keinginan publik tanpa harus bertentangan dengan peran dan fungsi Polri sebagaimana yang diatur dalam UU No. 2/2002 tentang Polri.

Tulisan ini akan menjelaskan bagaimana problematika kepolisian era transisi demokrasi dan bagaimana dengan konteks Indonesia. Makalah ini juga menawarkan bagaimana pengelolaan integratif citra baik Polri agar secara institusi mendapatkan respon positif dari publik, sedangkan secara personal, anggota Polri dapat

28 Lebih lanjut terkait dengan penjelasan bagaimana kesulitan sejumlah lembaga kepolisian dalam mengelola citra baiknya di era transisi demokratik, lihat Kadar, Andras. (ed). (2001). Police in Transition: Essays on the Police Forces in Transition Countries. Budapest: Central University Press. Lihat juga Ivkovic, Sanja Kuntjak. (2005). Fallen Blue Knight: Controlling Police Corruption. New York: Oxford University Press. 
secara aktif terlibat dan bertanggungjawab dalam pengelolaan citra baik Polri.

\section{Problematika Polisi Era Transisi Demokrasi}

Sejumlah akademisi dan peneliti tentang kepolisian menegaskan bahwa posisi kepolisian era transisi demokrasi menjadi tantangan serius bagi internal polisi sendiri. Beberapa akademisi yang menulis tentang kepolisian sebut saja misalnya Bayley ${ }^{29}$, Beltran ${ }^{30}$, Hinton $^{31}$, Kraska ${ }^{32}$, Pino dan Wiatrowski ${ }^{33}$. Dari sejumlah uraian dalam bukunya, ditarik benang merah terdapat enam permasalahan yang dihadapi oleh institusi kepolisian di negara-negara yang tengah menjalani transisi demokrasi dan atau negara dengan tradisi demokrasi yang belum mapan. Adapun enam permasalahan tersebut adalah sebagai berikut: Pertama, berpisahnya kepolisian dari militer di satu sisi berefek positif bagi polisi, tetapi di sisi yang lain juga menjadi permasalahan tersendiri bagi polisi. Beltran melihat bahwa proses pemisahan polisi dari militer yang relatif cepat tidak diikuti oleh kesiapan internal lembaga kepolisian. ${ }^{34}$ Sehingga, fase awal pemisahan polisi dari militer mendorong menguatnya jiwa korsa polisi yang dalam derajat tertentu tidak mencerminkan esensi dari kepolisian profesional.

Kedua, menguatnya jiwa korsa yang tidak tepat membuat pola hubungan dan koordinasi dengan institusi keamanan lainnya menjadi permasalahan tersendiri bagi polisi. Koordinasi yang paling krusial dalam penanganan keamanan oleh polisi bersama militer dan badan intelijen adalah ada pada wilayah abu-abu yang mana di negara-negara baru demokrasi belum diatur benar. ${ }^{35}$ Ada banyak terjadi di gesekan yang berakhir dengan bentrokan ataupun salah pengertian dalam operasionalisasi peran dan fungsinya.

29. Bayley, David H. (2001). Democratising the Police Abroad: What to Do and How To Do it. Washington: Department of Justice. Terutama Bab 1.

30. Beltran, Adriana. (June 2009). Protect and Serve? The Status of Police in Central America. Washington: WOLA. Terutama pembahasan pada Bab 3.

31. Hinton, Mercedes S. (2006). The State on the Streets: Police and Politics in Argentina and Brazil. Colorado: Lynne Reinner Publishers.

32. Kraska, Peter B. (2001). Militarizing the American Criminal Justice System: The Changing Roles of the Armed Forces and the Police. Boston: Northeastern University Press.

33. Pino, Nathan W. and Michael D. Wiatrowski (eds.). (2006). Democratic Policing in Transitional and Developing Countries. London: Ashgate.

34. Beltran. Op. cit. hal. 7-10.

35. Kraska. Op. cit. hal. 23-29. 
Ketiga, adalah permasalahan koordinasi dan hubungan dengan Criminal Justice System (CJS) khususnya pada peran dan fungsi kepolisian dalam penegakan hukum. Kekurangharmonisan hubungan ini selain disebabkan karena posisi polisi yang relatiflebih memiliki kewenangan paska berpisah dari militer, juga dikarenakan lembaga CJS yang ada cenderung memosisikan berlawanan atau setidaknya berposisi tidak mendukung peran dan fungsi kepolisian khususnya dalam penegakan hukum dikarenakan adanya perasaan bahwa institusi kepolisian memiliki kewenangan yang lebih dibandingkan dengan kejaksaan atau institusi CJS lainnya. ${ }^{36}$

Keempat, menguatnya tantangan ekonomi dan politik bagi institusi kepolisian. Pada konteks ekonomi, karena alasan selama bergabung dengan institusi militer, kepolisian relatif tidak terdukung tingkat kesejahteraannya, maka isu praktik korupsi dan penyalahgunaan kewenangan anggota kepolisian kerapkali terjadi. Bahkan dalam catatan Ivkovic, praktik korupsi menggejala dan merata pada institusi kepolisian selepas berpisah dari militer. Ada perasaan lebih tinggi dan cenderung menitikberatkan pada kenyataan bahwa selama bergabung dengan institusi militer, masalah kesejahteraan tidak diprioritaskan untuk ditingkatkan dengan berbagai alasan. ${ }^{37}$

Di sisi lain, upaya politisasi dan menyeret institusi kepolisian untuk mendukung rejim yang berkuasa juga menjadi tantangan tersendiri. Politisasi yang terjadi tersebut berawal dari proses pemilihan kepala kepolisian yang mana akan membangun ketergantungan secara politik institusi kepolisian pada rejim yang berkuasa. Hinton menggarisbawahi bahwa upaya politisasi tersebut bahkan lebih buruk dari era dimana kepolisian menjadi bagian dari militer. ${ }^{38}$ Hal tersebut dikarenakan posisi kepolisian tersandera oleh kepentingan rejim yang berkuasa dan cenderung dikendalikan untuk menjaga rejim agar tidak diganggu lawan politiknya.

Kelima, di era transisi demokrasi kewenangan baik peran dan fungsi kepolisian meningkat. Peningkatan peran dan fungsi ini berimplikasi pada kesiapan internal kepolisian dalam merespon penguatan kewenangan tersebut. Kesiapan internal tersebut diantaranya ada pada

36. Pino and Wiattrowski. Op. cit. hal. 123-124.

37. Ivcovic. Op. cit. hal. 235-236.

38. Hinton. Op. cit. hal. 113-114. 
pengendalian kepentingan internal kepolisian agar tidak berlawanan dengan esensi sebagai penegak hukum dan keamanan yang menjadi tugas dan peran kepolisian. ${ }^{39}$

Permasalahan yang terakhir, keenam, adalah upaya membangun dan mengelola pencitraan kepolisian yang kurang baik. Kadar mengakui bahwa selama era rejim otoriter, institusi kepolisian tidak dilatih atau terlatih untuk mengelola kepentingan kepolisian agar bercitra baik di mata publik. Hal ini berimplikasi pada bagaimana lembaga kepolisian kesulitan mengupayakan pencitraan baik di mata publik. Tak mengherankan apabila apa yang telah dilakukan oleh institusi kepolisian tidak tercitrakan atau sampai ke publik, namun justru sebaliknya semua prilaku negatif anggota kepolisian terekam dengan baik oleh publik. ${ }^{40}$

\section{Masalah di Indonesia}

Indonesia sebagai negara yang telah lama dipimpin oleh rejim otoriter pun kurang lebih sama dengan apa yang diuraian di atas. Hanya saja secara umum apa yang dialami oleh Polri cenderung merupakan refleksi dari budaya dan karakter politik yang ada. Paska berpisahnya Polri dari ABRI, sebagaimana yang diuraikan di atas, Polri juga mengalami berbagai cobaan dan tantangan yang pada derajat tertentu menjadi permasalahan serius bagi Polri sebagai institusi Kamdagri.

Ada empat permasalahan yang menjadi hambatan Polri dalam mengoptimalkan peran dan fungsinya yakni: Pertama, setelah berpisah dari ABRI, tantangan yang serius dihadapi oleh Polri adalah politisasi yang dilakukan oleh penguasa. Bermula saat Abdurrahman Wahid menjadi presiden hingga berlangsung sampai saat ini. Kepentingan penguasa didasari pada keinginan kontrol aktif pemerintah agar tidak berlawanan dengan agenda dan program yang ada. Salah satu yang paling kentara dilihat oleh publik adalah diciptakannya ketergantungan pimpinan Polri kepada pemerintah karena alasan 'utang politik' telah dipilih menjadi pimpinan institusi penegakan hukum tersebut. Hal yang menarik tersebut menguat terjadi di tingkat nasional dan terus berkurang pada level dan struktur di bawahnya. Dengan kata lain, makin kecil struktur dan keberadaan Polri, maka makin kecil pula kontrol politik

39. Bayley. Op. cit. hal. 79-81.

40. Kadar. Op. cit. hal. 193-194.

244 CosmoGov, Vol.1 No.2, Oktober 2015 
atas Polri. Selain karena Polri adalah kepolisian nasional, juga dikarenakan posisi Polri yang relatif mandiri dibandingkan posisi Polri di level nasional.

Kedua, permasalahan eksternal yang dihadapi oleh Polri. Masalah eksternal menyangkut soal bagaimana peran dan fungsi Polri dalam derajat tertentu dianggap tidak efektif oleh publik. Praktik penyimpangan kewenangan dalam bentuk penyalahgunaan kewenangan seperti pemerasan, korupsi, dan mengambil keuntungan pribadi dari peran dan fungsi yang dijalankan membuat citra Polri di mata publik tidak baik. Keinginan untuk memperkaya diri dengan mengedepankan arogansi kepolisian dan kekurangpahaman publik atas sejumlah aturan.

Ketiga, permasalahan internal yang masih membelenggu adalah respon-respon yang berkaitan dengan praktik peran dan fungsi kepolisian. Sebagai bagian dari pelaksana tugastugas pemerintahan, Polri tidak bisa lepas dari praktik birokrasi yang membuat proses administrasinya juga berbelit dan berlarut. Selain menyangkut soal kesiapan internal dalam mengubah paradigma kepolisian paska berpisah dari ABRI, juga disebabkan masih bercampur aduknya budaya militer yang membuat Polri kerapkali terjebak pada hierarkis dan arogansi institusi yang seharusnya tidak lagi dikedepankan.

Dan terakhir, keempat, masalah krusial lainnya adalah ada pada koordinasi dengan instansi terkait. Selain masalah pembagian kewenangan antara Polri dan TNI paska berpisah, Polri juga dihadapkan pada irisan kewenangan dengan sejumlah institusi semisal dengan Kejaksaan Agung, Kementerian Hukum dan HAM, serta dengan KPK. Tak jarang dengan sejumlah institusi terkait tersebut terjadi gesekan dan konflik yang mana membuat Polri di mata publik relatif tidak cukup baik.

\section{Polri dan Citra Baik}

Ada anggapan bahwa urusan menjaga citra baik Polri ada pada bagian Hubungan Masyarakat di tiap level dan struktur Polri. Anggapan tersebut tentu saja tidak benar, sebab sebagai satu institusi, Polri harus mengelola dengan baik citranya di mata publik dengan segenap potensi yang ada. Apa yang harus dilakukan Polri tentu memiliki korelasi dengan apa yang dicitrakan dan tetap mengupayakan agar prilaku negatif secara esensi berkurang.

Ada enam penegasan yang harus diperhatikan oleh Polri dalam pengelolaan citra baik Polri yang mana hal tersebut dilakukan secara integratif. Yakni: Pertama, perlu ditegaskan dan digarisbawahi bahwa setiap anggota Polri adalah Humas bagi institusinya. Hal ini penting untuk diingatkan agar setiap aktivitas yang dilakukan akan berimplikasi pada citra dan posisi baik Polri di mata publik. Dengan kata lain 
apa yang dilakukan oleh anggota, apakah menjalankan peran dan fungsinya secara optimal atau sebaliknya, bukan hanya dirinya saja yang dianggap tidak mampu, melainkan juga secara institusi. Kesadaran tersebut perlu dipahami oleh anggota sehingga ketika melakukan tugas dan fungsinya tidak keluar dari konteks semata-mata untuk kepentingan institusi dan publik.

Kedua, implikasi dari point pertama adalah anggota diharapkan menguasai permasalahan yang berkembang di masyarakat. Hal ini penting agar respon anggota Polri atas apa yang berkembang di masyarakat dapat selaras dengan apa yang diharapkan publik. Penguasaan permasalahan oleh anggota Polri menjadi wajib hukumnya manakala keberadaan Polri di tengah masyarakat menjadi sangat krusial.

Ketiga, sarana lainnya yang mampu membangun citra baik Polri di mata publik adalah optimalisasi program Perpolisian Masyarakat (Polmas). Selama ini program Polmas berjalan namun belum dioptimalkan sebagai bagian dari pondasi citraan baik Polri di mata publik. Keberadaan program yang telah berjalan sejak 2005 ini terkesan sebagai program yang tidak strategis. Hal ini tercermin dari bagaimana sebaran program ini belum memberikan stimulasi bagi pencitraan baik Polri di mata masyarakat. Kesan tersebut makin diperkuat ketika citra Polri tidak kunjung positif meski program tersebut telah berjalan lebih dari 8 tahun.

Keempat, kehumasan sebagai stimulasi citra baik Polri. Secara subyektif penulis menilai bahwa apa yang telah dilakukan kehumasan Polri sudah cukup baik. Hanya masalahnya ada pada penguasaan dan pendalaman permasalahan serta kesadaran internal dalam menjaga dan merawat Polri sebagai institusi tempat bernaung agar tetap baik di mata publik. Situasi inilah yang kemudian ditegaskan bahwa esensi kehumasan Polri adalah sebagai stimulator dan 'penyambung lidah' atau juga penyampai pesan baik kinerja Polri di masyarakat. Dengan kata lain, fungsi kehumasan Polri bukan untuk menyembunyikan hal-hal negatif atas nama Jiwa Korsa atau atas nama pencitraan baik Polri, kehumasan melakukan manipulasi atas informasi dan fakta yang berkembang.

Kelima, sebagai salah satu pilar demokratik dan industri, peran media menjadi sangat krusial dalam menghitamputihkan kasus atau permasalahan yang berkembang. Hal ini perlu disadari benar oleh Polri bahwa butuh energi dan tenaga ekstra agar media dapat sepenuhnya atau setidaknya tidak berlawanan dengan apa yang menjadi peran dan fungsi Polri. Dibutuhkan langkah-langkah yang bersifat praktis hingga filosofis agar media dapat selaras dengan kebijakan Polri atau setidaknya tidak menghambat langkah Polri. Media 
gathering yang dilakukan secara rutin serta anjang sana ke kantor redaksi media secara periodik menjadi alternatif bagi upaya menjalin hubungan yang baik.

Akan lebih baik lagi apabila staf kehumasan juga dilibatkan dalam interaksi tersebut. Sebab, fungsi administrasi kehumasan juga diharapkan kritis dalam melihat dinamika yang ada dan tidak terjebak oleh 'wartawan' koran-kuning atau wartawan 'CNN' yang hanya terbit manakala ada order atau sekedar disesuaikan dengan pemberi dana.

Dan yang terakhir, keenam, adalah pentingnya menggunakan kewenangan diskresi yang positif bagi kepentingan citra baik Polri. Deskresi positif ini harus didedikasikan bagi proses penguatan Polri sebagai institusi yang profesional dalam menjalankan peran dan fungsinya. Selama ini berkembang di publik bahwa penggunaan kewenangan deskresi hanya dilakukan untuk kepentingan individu dari anggota atau pimpinan semata. Sehingga efek positifnya bagi pencitraan Polri tidak terasa, setidaknya hal tersebut tercermin dari apa yang berkembang selama ini di tingkat masyarakat.

\section{Penutup}

Permasalahan yang dihadapi oleh institusi kepolisian di era transisi demokratik tersebut berimplikasi pada respon internal kepolisian sendiri. Selama ini kepolisian di sejumlah negara terus berupaya untuk mengurangi efek negatif dari permasalahan yang dihadapi di era transisi demokratik tersebut. Polri juga tidak lepas dari masalah yang dihadapi tersebut. Apa yang dirasakan oleh Polri hampir 15 tahun paska pergantian kekuasaan dari Orde Baru ke Orde Reformasi ini menjadi penegas bahwa karakteristik permasalahan yang dihadapi cenderung sama sebagaimana uraian di atas.

Karenanya, mengupayakan agar pencitraan baik publik terhadap Polri harus dilakukan secara integratif, tidak semata-mata menjadi beban dari kehumasan Polri. Dibutuhkan langkah yang berirama sama agar pengelolaan citra baik Polri dapat maksimal dilakukan. Akan tetapi perlu juga dipertegas bahwa keberadaan staf kehumasan sebagai penopang dari pimpinan harus mampu mengikuti irama permasalahan yang berkembang, agar apa yang dikelola selama ini tidak sekedar tumpukan kata dan kliping semata.

\section{Daftar Pustaka}

Bayley, David H., 2001.Democratising the Police Abroad: What to Do and How to Do It. Washington: Department of Justice.

Beltran, Adriana, 2009. Protect and Serve? The Status of Police in Central America. Washington: WOLA. 
Hinton, Mercedes S., 2006. The State on the Streets: Police and Politics in Argentina and Brazil. Colorado: Lynne Reinner Publishers.

Kadar, Andras. (ed), 2001. Police in Transition: Essays on the Police Forces in Transition Countries. B u d a pe st: Central University Press.

Kraska, Peter B., 2001. Militarizing the American Criminal Justice System: The Changing Roles of the Armed Forces and the Police. Boston: Northeastern University Press.
Muradi, 2009. Penantian Panjang Reformasi Polri. Yogyakarta: Tiara Wacana.

-----,2010.Polmas dan Profesionalisme Polri. Bandung: LCKI dan PSKN UNPAD.

-----, 2014. Politics \& Governance in Indonesia: The Police in the Era of Reformasi. London: Roudledge.

Ivkovic, Sanja Kuntjak, 2005. Fallen Blue Knight: Controlling Police Corruption. New York: Oxford University Press.

Pino, Nathan W. and Michael D. Wiatrowski (eds.), 2006. Democratic Policing in Transitional and Developing Countries. London: Ashgate. 